The Historical Journal, 23, 4 (1980), Pp. 939-947.

Printed in Great Britain

\title{
THOMAS BABINGTON MACAULAY AND FREDERICK THE GREAT
}

\author{
TIMOTHY C. F. STUNT \\ Aiglon College, Chesières, Switzerland
}

\begin{abstract}
It was in $184^{1}$ that Macaulay became fully aware how far he was 'seriously engaged in an extensive work which will probably be the chief employment of the years of health and vigour which may remain to me'. In consequence he decided to select the subjects for his reviews more carefully. Although he did not want these essays to pre-empt his History, Macaulay had equally no wish to 'engage in any extensive researches altogether alien from what is now my main object'. Writing to the editor of the Edinburgh Review, he illustrated this working principle by explaining why Frederick the Great seemed an ideal subject for a review:

His personal character, manners, studies, literary associates; his quarrel with Voltaire, his friendship for Maupertuis, and his own unhappy metromanie will be very slightly, if at all alluded to in a History of England. Yet in order to write the History of England, it will be necessary to turn over all the Memoirs, and the writings of Frederic, connected with us, as he was, in a most important war.'
\end{abstract}

Macaulay was suggesting that as he was already obliged to study the life of the Prussian king in some depth, a review of Campbell's Frederic the Great and his times, published in November 1841 , would be a useful by-product of his current researches.

At the end of December he was still enthusiastic:

I think Frederic a capital, indeed an incomparable, subject. I only regret that I have never seen Berlin and Potsdam. But still I hope to furnish you with something that people will be willing to read. ${ }^{2}$

Although one might have thought that Warren Hastings and Clive were far more likely subjects for the enthusiasm of a former imperial administrator, evidently Frederick attracted him more:

l ought to produce something much better than either of these articles [on Warren Hastings and Clive] with so excellent a subject as Frederic. ${ }^{3}$

It is a commonplace that when Carlyle devoted twelve years to his portrayal of Frederick the Great, he identified his own predicament and struggles with those of the Prussian king, and that he was presenting Frederick as a hero whose example his contemporaries sorely needed. In Professor Clive's words, 'Certainly some process of identification took place between the Prussian King, beset by enemies and almost at bay on several occasions, and the sage of Chelsea pursuing his monumental task in the face of ill health and exhaustion.' 4 Carlyle's experience however was clearly very different from the attraction that drew Macaulay to Frederick, and when he read Carlyle's first two volumes in 1858 , Macaulay's comment was scathing as he dismissed the philosophy as nonsense and the style as gibberish. ${ }^{5}$

1 Thomas Pinney (ed.), Lelters of Thomas Babington Macaulay (Cambridge, 1971-7), 1v, 17-18.

2 Pinney, Macaulay's letters, Iv, 19.

4 John Clive (ed.), Thomas Carlyle: history of Frederick the Great (Chicago, 1969), p. xxv.

5 R. C. Beatty, 'Macaulay and Carlyle', Philological Quarterly, xviII (1939), p. $3^{2}$.

0o18-246X/80/2828-383o \$o2.50 (C) 1980 Cambridge University Press 
Although Macaulay's essay is omitted from the more recent editions of his work, its portrayal of Frederick seems to have had a particular appeal in the half century following 1870 when German nationalism seemed to have justified itself and when British Francophobia was far from dead. Significantly, no less than three editions of the essay were published between 1909 and 1914 , the editor of one of which claimed that this essay was 'among the best known of the whole collection [of Macaulay's essays]' and that 'it would not be an exaggeration to say that to most English readers of history the picture of Frederic which is most familiar is the picture drawn in these pages by Macaulay'.? It would seem, therefore, not inappropriate to investigate the nature of Macaulay's own enthusiasm for Frederick as it is possible that this may have at least some bearing on the essay's later popularity.

There are three obvious fields of similarity between Thomas Babington Macaulay and the subject of Thomas Campbell's biography: their political attitudes, their literary interests and their family circumstances. But before we enlarge on these, it must be emphasized that we are not making a facile comparison that would imply that Frederick and Macaulay were basically similar characters. Indeed, this is clearly far from the case. In his essay, Macaulay often expresses his disapproval of his subject, and yet at the same time exhibits in his writing a personal sympathy which is remarkable in view of his evident dislike of some of Frederick's actions and policies. It would appear that, probably subconsciously, Macaulay felt that there were mitigating circumstances which had to be borne in mind when making these judgements.

As far as political attitudes were concerned there is at first sight little common ground between the cynical realism of Frederick and the idealistic theories of the whig politician. On the other hand, Macaulay emphasizes at least one of Frederick's 'titles to praise':

A great liberty of speaking and writing was allowed ... No person would have dared to publish in London, satires on George the Second approaching to the atrocity of those satires on Frederic, which the booksellers at Berlin sold with impunity... Even among statesmen accustomed to the license of a free press, such steadfastness as this is not very common. ${ }^{8}$

Added to this there was Frederick's abolition of torture, his concern for cheap and speedy justice and his championship of religious liberty. That Macaulay saw these policies as the essence of a truly liberal spirit is evident in the allowances that he made for Frederick's one failure in this respect.

Religious persecution was unknown under his government, unless some foolish and unjust restrictions which lay upon the Jews may be regarded as forming an exception. ${ }^{8}$

- I.e. G. M. Young (ed.), Macaulay: prose and poetry (London, 1952); H. Trevor-Roper (ed.), Macaulay: critical and historical essays, (London, 1965); J. Clive and T. Pinney (eds.), Selected writings of Thomas Babington Macaulay (Chicago, 1972).

7. C. T. Atkinson (ed.), Lord Macaulay: Frederic the Great (Oxford, 1914), p. iv. Other editions were H. W. C. Davis (ed.), Lord Macaulay: essay on Frederic the Great (London, I909); D. Salmon (ed.), Macaulay's essay on Frederic the Great (London, 1913).

8 'Frederic the Great' (Apr. 1842) in Lord Macaulay, Essays and lays of ancient Rome (London I 89o, popular edn), p. 807. Frederic's tolerance is confirmed by Walther Hubatsch, Frederick the Great of Prussia : absolutism and administration (London, 1975), p. 40. John Clive's most recent assessment of Macaulay confirms that Frederick's maintenance of a 'free press' was an

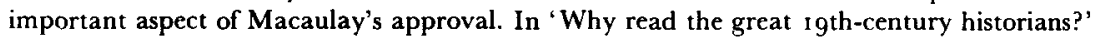
he argues that Macaulay's distinctive interest both in his History and in his political life was with the 'public mind' and 'public opinion'. The American Scholar, xLvIII, I (I $\left.97^{8-9}\right), 4^{2-8}$.

- Macaulay, Essays, p. 807. 
One would hardly have expected such leniency from a politician whose maiden speech in April 1830 had been concerned with the removal of Jewish disabilities, unless Macaulay was sure that in the root of the matter, Frederick and he were in basic agreement. Indeed, the only context in which Macaulay finds the Prussian king seriously illiberal is his 'spirit of meddling'. Although Frederick's heart seems to be in the right place and his aims are praiseworthy, nevertheless Macaulay finds that he is guilty of using illiberal or interventionist methods to achieve these ends. Thus:

He firmly believed that he was doing right, and defending the cause of the poor against the wealthy. Yet this well meant meddling probably did far more harm than all the explosions of his evil passions during the whole of his long reign. ${ }^{10}$

Macaulay's strength of feeling in this criticism perhaps reflects his own experiences as a member of the whig cabinet in $1840-1$. His nephew G. O. Trevelyan instances at least two cases where Macaulay found himself opposing apparently reasonable demands for change.

Over a bill dealing with the registration of voters in Ireland he argued that 'almost every clause of this Bill which is designed for keeping out the wrongful, acts just as effectually against the rightful claimant'. ${ }^{11}$ Similarly in ${ }_{104} 1$ Macaulay 'had very little to do in the House of Commons except to defend Lord Cardigan'. It was a distasteful task and he had to 'put as best face he could' on the ugly stories that were circulating. Again, he had to withstand, albeit half-heartedly, interference (or meddling) with the system, maintaining that

Honourable gentlemen should beware how they take advantage of the unpopularity of an individual to introduce a precedent which if once established, would lead to the most fatal effects to the whole of our military system and work a great injustice to all the officers in Her Majesty's service. ${ }^{12}$

Of course these episodes may be cited by Professor Hamburger as further proof that Macaulay was a 'trimmer' rather than a true whig, in politics as well as in his writing of British history. Such a claim however is too restrictive in its definition of 'whig'. Macaulay's most recent editors are more judicious when they remind us that

By Whig history is not meant history given to the indiscriminate praise of Whigs and their relatives. The term refers, rather to the evident faith of such history in the reality of progress, and to the view which underlines that faith. This view may be defined as that which, taking the present as the measure of things, praises and blames the men and events of the past according to whether they do or do not lead toward the condition of the present. In this sense Macaulay is certainly a Whig. ${ }^{13}$

A similar point could be made concerning Macaulay's political standpoint in I 840-I. Clearly his attitudes are better described as Liberal rather than whig, but the former must not be assumed to exclude the latter. Certainly Macaulay's criticism of Frederick's interventionist 'meddling' derives from his belief that such policies obstructed the progress which otherwise could be said to characterize his domestic achievement.

As far as foreign policy is concerned, one again finds that Macaulay's disapproval of Frederick is mollified by a certain underlying admiration and respect. He is under

10 Ibid. p. 808

11 George Otto Trevelyan, The life and letters of Lord Macaulay (London, I 89o, popular edn), p. 392 .

12 Ibid. pp. 399-400.

13 Clive and Pinney, Macaulay's selected writings, p. xxiii. 
no illusion as to Frederick's responsibility for the war both in 1740 and in 1744 and presents him as the aggressor:

The whole world sprang to arms. On the head of Frederic is all the blood which was shed in a war which raged during many years and in every quarter of the globe...14

Nevertheless, when the 'diplomatic revolution' becomes a possibility, and France begins to plot with Austria against Prussia, then Frederick begins to emerge in Macaulay's account as something of a hero. Macaulay makes no effort to see the alliance against Frederick in $175^{6}$ as a logical consequence of his earlier policies. Instead, he maintains that it was not 'to any political theory that the strange coalition between France and Austria owed its origin. The real motive...was personal aversion to the King of Prussia.' He explains that Frederick's satirical verses were bound to upset the rulers of Europe especially as Frederick was a misogynist and as 'almost the whole continent was then governed by women who were by no means conspicuous for meekness'. ${ }^{16}$

One of Macaulay's Edwardian editors observed in Igog that it is puerile to maintain that the private feelings of Maria Theresa, the Czarina Elizabeth and Madame de Pompadour account for the overthrow of the European system'.16 Macaulay's espousal of such an explanation merely serves to demonstrate that by 1756 there is for him no longer any doubt who is the villain of the piece. Indeed, with the battle of Rossbach in 1757 Frederick is almost transformed into the champion of the free world which already, in Macaulay's perspective, seems to be threatened by the shadow of Napoleon:

Then first it was manifest that the Germans were truly a nation. Then first was discernible that patriotic spirit which, in $8_{1} 3$, achieved the great deliverance of central Europe, and which still guards, and long will guard, against foreign ambition the old freedom of the Rhine. ${ }^{17}$

Of course it can be argued reasonably that in his approval of Frederick in the Seven Years War, Macaulay is merely adopting the traditionally whig point of view which found fault with Bute and George III for their abandonment of the heroic Frederick in $1762-3$. On the other hand, Macaulay's attitude may again be related to the political situation in which he found himself as minister at war in 1840 .

Not only was Macaulay obliged, in April, to defend the British attack on China in the Opium War, but also he was involved in Paimerston's alliance with Russia, Austria and Prussia and in his ultimatum to Egypt and France over the current phase of the Eastern question. Writing in December, he justified his position:

I am satisfied that the War party in France is insatiable and unappeasable... Is it for such friendships as this that our country is to abdicate her rank, and sink into a dependency?... It is foolish and wicked to bellow for war, merely for war's sake, like the rump of the Mountain at Paris. I would never make an offensive war. I would never offer to any other power a provocation which might be a fair ground for war. But I never would abstain from doing what I had a clear right to do, because a neighbour chooses to threaten me with an unjust war...I think war, though a very great evil, by no means so great an evil as subjugation, and national humiliation. ${ }^{18}$

Is it perhaps, therefore, not too fanciful to suggest that Macaulay's own current Francophobia gave him a further bond of sympathy with Frederick, once the Prussian king had shed his earlier alliance with France? Certainly his letter to Napier

\footnotetext{
14 Macaulay, Essays, p. 801.

16 Davis, Macaulay's Frederic, p. viii.

15 Ibid. p. 818.

17 Macaulay's Essays, p. 827.
}

18 Trevelyan, Macaulay, pp. 396-7. 
in February 1842 indicates that his own political activity had, amongst other things, interrupted his writing of the essay:

I have been so much occupied by politics and by the society which at this season fills London, that I have written nothing for some weeks. I will however set to work again on Frederic. You expect infinitely too much. The article, I am afraid, will want interest. I cannot get on fast with it. For I am under necessity of grubbing in German memoirs and documents which I do not read with great facility. I heartily wish that you could give me a respite till July. ${ }^{19}$

When we come to the field of literary endeavour we must tread carefully, as Macaulay himself would undoubtedly have been appalled at the suggestion that there was any such parallel between Frederick and himself. However, there are two aspects of the question to be considered. First, although Macaulay is fairly scathing about Frederick's prose and verse, ${ }^{20}$ he goes out of his way to make allowances for the king, recognizing that French was not his mother tongue, and that his admiration for Voltaire's writings was the inevitable outcome of his deficiency in any other language. In saying this, it is possible that Macaulay's tolerance was prompted by his dissatisfaction with his own compositions. Back in 1832 he had wondered,

whether any man ever wrote doggerel so easily. I run it off just as fast as my pen can move, and that is faster by about three words in a minute than any other pen I know. This comes of a schoolboy habit of writing verses all day long. ${ }^{21}$

Ten years later when he was preparing the Lays of ancient Rome for the publisher, he wrote that 'though they are but trifles, they may pass for scholarlike and not inelegant trifles'. ${ }^{22}$ Evidently Macaulay was well aware of the transient value of his own verse, even though it received high praise when it was published, a few months after his essay on Frederick. The fact that 'by June 1875 , upwards of a hundred thousand copies had passsed into the hands of readers', ${ }^{23}$ tells us more about Victorian reading habits than about the quality of Macaulay's verse. On the other hand, if his verse was ephemeral, his prose was not always as effortless as one might be inclined to suppose. With the essay on Frederick, for example, he admitted to Napier on 28 February, 'I do not take to this subject', even though it had seemed attractive at first, and a month later he was hoping that "the public will like it better than I do. I was never so little pleased with a performance of my own'. ${ }^{24}$ A man as dissatisfied as that was able to understand Frederick's lack of gift.

The second aspect of their literary similarity is concerned with the circumstances of their writing.

In the midst of all the great King's calamities, his passion for writing indifferent poetry grew stronger and stronger. Enemies all round him, despair in his heart, pills of corrosive sublimate hidden in his clothes, he poured forth hundreds upon hundreds of lines, hateful to gods and men... at this very time [the last months of 1 757] the scanty leisure of the illustrious warrior was employed in producing odes and epistles, a little better than Cibber's and a little worse than Hayley's... We hardly know any instance of the strength and weakness of human nature so striking, and so grotesque, as the character of this haughty, vigilant, resolute, sagacious. bluestocking, half Mithridates and half Trissotin, bearing up against a world in arms, with an ounce of poison in one pocket and a quire of bad verses in the other. ${ }^{25}$

19 Pinney, Macaulay's letters, Iv, 22.

20 'Nature... had withheld from him those higher and rarer gifts without which industry labours in vain to produce immortal eloquence and song.' Macaulay, Essays, p. 796.

21 Pinney, Macaulay's letters, II, 155. $\quad{ }^{22}$ Ibid. IV, 44. $\quad{ }^{23}$ Trevelyan, Macaulay, p. 426.

24 Pinney, Macaulay's letters, Iv, 22, 24.

25 Macaulay, Essays, p. 823 . 
Such was Macaulay's apparently scornful assessment of his subject's 'unhappy metromanie'. Nevertheless, although his comments seem acid enough, there was probably in his heart some sympathetic response to this strange phenomenon which was not so alien to his own experience. In Edinburgh for example in 1847 , after electoral defeat, we find him 'weaving his perturbed thoughts into those exquisite lines which tell within the compass of a score of stanzas the essential secret' of his life. ${ }^{26}$ It was of course, Macaulay's nephew who found the verses exquisite, but Sir Leslie Stephen's comment was at once less extravagant but more explicit: 'Macaulay, on the same evening wrote an eloquent copy of verses, showing how literature had been his consolation under all the trials (of which it was rather difficult to make a respectable list) of his life.' In fact there had been many trials but they were primarily of a domestic sort, but what emerges both from Professor Clive's biographical study and from the edition of Macaulay's letters, currently in the care of Professor Pinney, is that repeatedly, Macaulay's literary activities proved a source of relief during times of emotional stress when more than once he seems to have been near to breakdown. It is only logical therefore that we turn now to consider the domestic side of his experience in which, once more, Macaulay was able to identify with Frederick.

Writing at the end of the last century, Sir Leslie Stephen observed of Macaulay that 'the absence of any trace of love affairs in the life of so true hearted and masculine a nature is unexplained'. ${ }^{27}$ More recently the publication of his letters has spelt out very explicitly what was already clearly indicated in Trevelyan's biography - namely the deep affection that Macaulay entertained for his younger sisters Margaret and Hannah. Professor Clive has related this to the conflict (which Trevelyan minimized) between Macaulay and his austere Evangelical father. The incurably literary boy who declined to wear his religious heart on his sleeve was bound to clash with his father, who was famed for his high-minded philanthropy. The parallel between this situation and the early years of Frederick the Great is more than obvious. Macaulay's description of the Prussian crown prince's predicament makes the point admirably:

The Prince Royal, too, was not one of those who are content to take their religion on trust. He asked puzzling questions, and brought forward arguments which seemed to savour of something different from pure Lutheranism. The King suspected that his son was inclined to be a heretic of some sort or other, whether Calvinist or Atheist his Majesty did not very well know. ${ }^{28}$

It would of course be misleading to suggest that Zachary Macaulay ever turned into anything like the demented tyrant that Frederick William I became, and there is little to indicate that Tom Macaulay had to put up with anything of the savagery that Frederick endured, nevertheless the tension was there. In the recently published recollections of Macaulay's sister Frances, the situation is well illustrated:

His opinions on many subjects religious \& political as he grew to manhood differed greatly from those of his Father \& Mother \& I can recall with intense pleasure many discussions \&

26 Trevelyan, Macaulay, p. 474.

27 Dictionary of national biography, xII, 415, 418.

28 Macaulay, Essays, p. 794. Cf. ' His statements of faith gradually became ambiguous and calculated, as he made them into a weapon of his opposition - a telling weapon, since it was aimed at his father's conscience and religious scruples.' Carl Hinrichs, 'The conflict between Frederick and his father', in Peter Paret (ed.), Frederick the Great: a profile (New York, 1972), p. II. 
conversations wh on his side were ever conducted with the deepest respect $\&$ a self restraint really marvellous. ${ }^{29}$

Macaulay's experience gave him some immediate sympathy with the persecuted Frederick, even if his own father was milder and less violent. "That the strain between father and son never became a break was primarily due to the son's continued willingness to yield, at no little cost to his own inclinations when confronted by the paternal wrath' ${ }^{30}$ It is just possible that at some stage in his life Macaulay drew his sisters' or nephew's attention to this aspect of the parallel with Frederick, because it is referred to by Trevelyan in his biography. Macaulay's letters to his father included an occasional anecdote 'bearing upon the question of Slavery' and this

reminds the reader of those presents of tall recruits with which, at judiciously chosen intervals, Frederic the Great used to conciliate his terrible father. ${ }^{31}$

In the partial estrangement from his father that his other interests produced, Macaulay was thrown more and more into the company of his sisters, who shared his literary tastes and to whom he felt deeply attracted. In Professor Clive's words, "the sisters provided a retreat, a "park" in which Macaulay, at odds with his own father, could himself play the role of father to his younger sisters'. ${ }^{32}$ Inevitably his grief was traumatic when the sisters married and when, shortly afterwards, Margaret died. In his essay, Macaulay mentions that Frederick and his sister Wilhelmina were both 'in an especial manner objects of his [Frederick William's] aversion', and when describing Wilhelmina's death he notes:

she was and deserved to be, Frederic's favourite sister. He felt the loss as much as it was in his iron nature to feel the loss of anything but a province or a battle..$^{33}$

Here it is difficult to avoid the suspicion that Macaulay was only too well aware of the parallel with his own experience, and was deliberately playing down Frederick's attachment to his sister. In fact, during their childhood, the bond between the future king and his sister had been forged for life.

She was his most intimate friend, confidante and emotional mainstay. Together they read the classics, dressed up, played duets, versified, invented a code language and exchanged satirical remarks over the heads of the uninitiated. ${ }^{34}$

Although there was a period of estrangement for a while, Frederick's attachment to his sister became more profound than ever in their later life. If Gerhard Ritter's analysis is a fair one, then Macaulay must have had little difficulty in identifying with Frederick:

After so many friends and companions of his youth had been killed...the close relationship between sister and brother grew even more intense, and finally reached heights of almost violent affection. It seemed as though the two wanted to cling to each other to keep from being psychically paralyzed by the storms of fate. ${ }^{35}$

29 Randolph J. Bufano (ed.), 'An unpublished memoir of Lord Macaulay', Notes and Queries, n.s. xxv (June 1978$), 241$.

30 John Clive, Thomas Babington Macaulay, the shaping of the historian (London, I973), p. 54 .

${ }^{31}$ Trevelyan, Macaulay, p. 98. 'He could always be propitiated by a present of a grenadier of six feet four or six feet five; and such presents were from time to time judiciously offered by his son.' Macaulay, Essays, p. 797.

32 Clive, Macaulay, p. 499 .

${ }^{33}$ Macaulay, Essays, pp. 793, 829.

${ }^{34}$ Edith Simon, The making of Frederick the Great (London, 1963), p. 46.

${ }^{35}$ Gerhard Ritter, Frederick the Great: an historical profile (London, 1968), p. I 1 . 
This extreme anguish during the last months of Wilhelmina's life is amply expressed in numerous letters that he wrote:

You, the dearest of my family, the dearest person in the world, keep alive so that I may at any rate have the consolation of being able to shed my tears on your bosom.

Think what would become of me if I lost you. Oh my dear, my divine sister, do the impossible and recover. My life, my happiness, my existence is in your hands.

Writing to his brother Henry, he exclaims:

After our good mother she is the person I love most tenderly, a sister who possesses all my heart and all my confidence, and whose character is beyond the price of all crowns in the world. ${ }^{36}$

Unlike Macaulay who never married, Frederick took a wife, principally to establish himself at some distance from his father in a separate household. It was a loveless union, and the letters quoted above would seem to suggest that his affection for his sister might have prevented almost any wife from enjoying much of his affection. Of all this Macaulay must have been aware, and it is unlikely that he never compared himself with Frederick in this respect. There had been a similar tension in his own thinking in 1832 , a year before his sister Margaret married, when he wrote, 'I do not know how love in a cottage may do with a wife. But I am sure it would suit me with a sister. ${ }^{37}$

When Macaulay died in 1859 he had only seen the first two volumes of Carlyle's work on Frederick and this was perhaps just as well, because in addition to his dislike of Carlyle's style to which we alluded earlier, Macaulay might well have failed to appreciate Carlyle's detailed extracts from Frederick's anguished letters protesting his affection for Wilhelmina, many of which appeared in book xvII of the magnum opus. In fact even Carlyle had finally to draw a veil over the intensity of this potentially incestuous relationship:

The loss of his Wilhelmina, had there been no other grief, has darkened all his life to Friedrich. Readers are not prepared for the details of grief we could give, and the settled gloom of mind they indicate. A loss irreparable and immeasurable; the light of life, the one loved heart that loved him, gone. ${ }^{38}$

We noted earlier the claim made by one of Macaulay's editors in 1914 that it was his picture of Frederick rather than Carlyle's that was familiar to the English reading public. Obviously, the length and opacity of Carlyle's writing was the principal factor in this preference, but it is possible too that the last part of our comparison between Macaulay and Frederick may shed some further light on this phenomenon. 'It has often been pointed out that in some ways Frederick's father...was fundamentally closer to Carlyle's heart than Frederick himself, with whose aesthetic tastes and accomplishments Carlyle had little sympathy' ${ }^{39}$ In contrast, Macaulay's feelings were with the rebellious, freethinking son whose faith is wavering but who follows in the path of his father in spite of his doubts. Perhaps late Victorian and Edwardian readers, so many of whom were undergoing a crisis of faith, identified with Macaulay's Frederick more easily in consequence. On the other hand, the same readers perhaps were indeed, 'not prepared for the details' that Carlyle gave of

${ }^{36}$ G. P. Gooch, Frederick the Great, the ruler, the writer, the man (London, I947), Pp. 233-4.

37 Pinney, Macaulay's letters, II, I 48.

38 Thomas Carlyle, History of Friedrich $I I$ of Prussia (London n.d.), vi, book 19, ch. 1, p. 5 .

30 Clive, Carlyle's Frederick, p. xxxiv. 
Frederick's affection for his sister. In this respect too, Macaulay's restraint may possibly have been more acceptable to late Victorian society.

These last suggestions must, for want of more detailed inquiry, remain purely conjectural. What, however, seems almost a certainty is that Macaulay's own original enthusiasm for Frederick as an essay subject was not solely (as he had suggested to Napier) because it fitted in with the programme that he had set himself for his History of England. In her brief study of Macaulay, Ms Jane Millgatc observes of the subjects of his essays that 'few of these figures would rank high on a conventional list of heroes' and that 'they are all flawed in some ways'. She argues that 'Macaulay set out... with the intention of painting these flawed or unexciting beings precisely as they were, balancing the good points against the bad, emphasizing greatness where it could be found ' ${ }^{40}$ In the case of his essay on Frederick the Great, Macaulay could evidently understand the flaws very well because there were familiar parallels in his own life, with the result that probably Frederick's strange career was already a source of fascination to him. His ability to identify his own experiences with certain aspects of Frederick's predicament bears out the suggestion of John Clive and Thomas Pinney when they say that Macaulay's essays 'gave him a chance to display the scenes and characters which he loved to dwell on in imagination '. ${ }^{41}$

40 Jane Millgate, Macaulay (London, 1973), p. 97.

41 Clive and Pinney, Macaulay's selected writings, p. xv. 